\title{
Partial Splenic Embolization may be an Option to Overcome Thrombocytopenia Interfering with Triple Therapy in HCV (+) Cirrhotic Patients: A Case Report
}

\author{
Parsiyel Splenik Embolizasyon Üçlü Tedavi Alan Sirotik Hastalarda Trombositopeniyle \\ Mücadelede Bir Seçenek Olabilir: Bir Olgu Sunumu
}

\author{
Mehmet ASIL1, Murat BIYIK1, Sami ÇIFÇI1, Serhat SAYIN2, Ramazan UÇAR2, Orhan ÖZBEK3, \\ Hüseyin ATASEVEN1, Hakkı POLAT1, Ali DEMIR1
}

${ }^{1}$ Necmettin Erbakan University Faculty of Medicine, Department of Gastroenterology, Konya, Turkey 2Necmettin Erbakan University Faculty of Medicine, Department of Internal Medicine, Konya, Turkey

${ }^{3}$ Necmettin Erbakan University Faculty of Medicine, Department of Radiology, Konya, Turkey

\begin{abstract}
Various drug-related side effects are frequently encountered in patients receiving interferon-containing treatment regimens for chronic hepatitis C. Such side effects sometimes necessitate drugs be given in suboptimal doses or even discontinuation of the treatment. Thrombocytopenia is frequent in patients receiving interferon and complicates treatment course. Here, we present a case of hepatitis $\mathrm{C}$ virus $(\mathrm{HCV})(+)$ cirrhotic patient in whom splenic embolization was successfully performed in order to overcome thrombocytopenia associated with pegylated interferon (PEG-IFN)+ribavirin+telaprevir triple therapy. A 47-year-of woman was being followed in our clinic due to HCV-related cirrhosis for 6 years. She was given PEG-IFN+ribavirin treatment for 48 weeks 6 years ago and HCV infection relapsed. After the approval of protease inhibitorcontaining triple therapy regimens in genotype $1 \mathrm{~b} \mathrm{HCV}(+)$ patients in our country, such treatment was planned. Laboratory investigations were consistent with Child class A cirrhosis. Abdominal ultrasound showed the presence of cirrhosis and splenomegaly. HCV RNA was 756000 copy $/ \mathrm{ml}$. Pretreatment hematologic parameters were as follows; Hb: $11.8 \mathrm{~g} / \mathrm{dL}$, WBC: $4600 / \mu \mathrm{L}$ and platelet count: $64000 / \mu \mathrm{L}$. Treatment was started with PEG IFN $\alpha$-2a $135 \mathrm{mcg} /$ week, ribavirin $1000 \mathrm{mg} /$ day and telaprevir 3x750 mg/day. Platelet count dropped gradually to $42000 / \mu \mathrm{L}$ and than to $14000 / \mu \mathrm{L}$ in two weeks. PEG-IFN dose was progressively reduced up to $67.5 \mathrm{mcg} /$ week. To overcome thrombocytopenia, partial splenic embolization was performed. Platelet count increased to 45000 $/ \mu \mathrm{L}$ in 1 week and PEG-IFN dose was increased back to $135 \mathrm{mcg} /$ week. Throughout the rest of the treatment, platelet count remained around $60.000 / \mu \mathrm{L}$ and she successfully completed a 48-week treatment course. Both end-treatment and $12^{\text {th }}$ week post-treatment HCV RNA were negative. Treatment of severe thrombocytopenia with splenic embolization may be an effective minimally invasive option in HCV (+) cirrhotic patients in whom PEG-IFN-containing triple treatment regimens are given.
\end{abstract}

Keywords: Chronic hepatitis C, cirrhosis, interferons, protease inhibitors, telaprevir, thrombocytopenia

\section{$\ddot{0 Z Z}$}

Kronik hepatit $\mathrm{C}$ nedeniyle interferon içeren tedavi rejimleri uygulanan hastalarda ilaçlara bağlı yan etkilerle sıkıkla karşılaşılmaktadır. Bu yan etkiler bazen ilaçların suboptimal dozlarda verilmesine hatta tedavinin kesilmesine neden olabilmektedir. Interferon alan hastalarda trombositopeni sık görülür ve tedaviyi zorlaștırır. Biz burada Pegile interferon+ribavirin+telaprevir üçlü tedavisi alan ve tedaviyi etkileyen trombositopeni tedavisi için splenik embolizasyon uygulanılan hepatit $\mathrm{C}$ virüs $(\mathrm{HCV})(+)$ sirotik bir hastayı sunmayı amaçladık. Kırk yedi yaşında kadın hasta kliniğimizde $H C V(+)$ siroz nedeniyle 6 yıldır takip edilmekteydi. Altı yı önce 48 hafta pegylated interferon (PEGIFN)+ribavirin tedavisi almış ve tedavi sonrası relaps saptanmıştı. Proteaz inhibitörü içeren $3^{\prime}$ lü tedavi protokollerinin genotip $1 \mathrm{~b}$ hastalarda ülkemizde de onaylanmasından sonra hastaya telaprevir içeren $3^{\prime}$ lü tedavi protokolü planlandı. Hastanın tedavi öncesi laboratuvar tetkikleri Child A sirozla uyumluydu. Abdominal ultrasonografide kronik karaciğer hastalığı bulguları ve splenomegali saptandı. Tedavi öncesi HCV RNA

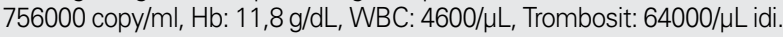
Hastaya Peg IFN $\alpha$-2a $135 \mathrm{mcg} / \mathrm{hafta}$, ribavirin $1000 \mathrm{mg} / \mathrm{gün}$ ve telaprevir $3 \times 750$ mg/gün başlandı. Iki hafta içerisinde trombosit sayımı önce 42000 $/ \mu \mathrm{L}$ ve ardından $14000 / \mu \mathrm{L}$ 'ye kadar düştü. PEG-IFN dozu kademeli olarak $67,5 \mathrm{mcg} / \mathrm{haftaya}$ kadar azaltıldı. Trombositopeni nedeniyle hastaya parsiyel splenik embolizasyon uygulandı. Bir hafta içerisinde trombosit sayısı 45000/uL'ye yükseldi ve PEG-IFN dozu tekrar 135 mcg/haftaya arttırıldı. Tedavinin geri kalan kısmında trombosit sayısı yaklaşık 60000/ $\mu \mathrm{L}$ civarında seyretti ve hasta 48 haftalık tedaviyi başarıyla tamamladı. Hastaya tedavi sonu ve tedavi bitiminden 12 hafta sonra bakılan HCV RNA (-) olarak saptandı. PEG-IFN içeren üçlü tedavi tedavi protokolleri uygulanacak olan sirotik hastalarda trombositopeni tedavisinde splenik embolizasyon minimal invaziv bir seçenek olarak kullanılabilir. Anahtar Kelimeler: Kronik hepatit C, siroz, interferonlar, proteaz inhibitörleri, telaprevir, trombositopeni

Address for Correspondence: Mehmet Asil MD, Necmettin Erbakan University Faculty of Medicine, Department of Gastroenterology, Konya, Turkey Phone: +90 5054007407 E-mail: drmehmetasil@yahoo.com.tr Received: 20.03.2015 Accepted: 06.10.2015 


\section{Introduction}

Chronic hepatitis $\mathrm{C}$ is an important health problem and the leading cause of liver cirrhosis and hepatocellular carcinoma worldwide (1). Until recently pegylated interferon (PEG-IFN) and ribavirin combination was the only treatment option for the treatment of chronic hepatitis $\mathrm{C}$ and such treatment was associated with relatively low cure rates (2). However, in the last few years, new IFN-free treatment regimens are approved for the treatment of chronic hepatitis $\mathrm{C}$ with up to $90-100 \%$ reported sustained virologic response (SVR) rates $(3,4)$. High costs of such treatments limit their use worldwide. Also in countries where such drugs are not still approved for the treatment of hepatitis C, IFN-based regimens are still the only therapeutic option. Drug side effects are one of the major concerns for IFN-based treatment regimens and hematologic side effects, such as leucopenia and thrombocytopenia, are common. Thrombocytopenia is of particular importance in cirrhotic patients because deepening of preexisting thrombocytopenia in these patients may cause treatment with suboptimal doses of PEG-IFN with resultant decrease in SVR rates. Triple treatment regimens with PEGIFN, ribavirin and protease inhibitors are shown to be superior to PEG-IFN+ribavirin for genotype $1 \mathrm{~b}$ patients $(5,6)$. However triple regimens with telaprevir are also associated with higher rates of therapy discontinuation due to side effects (6). Partial splenic embolization (PSE) is a therapeutic option to treat thrombocytopenia in cirrhotic patients. Here, we present a case of hepatitis $\mathrm{C}$ virus $(\mathrm{HCV})(+)$ cirrhotic patient in whom splenic embolization was successfully performed in order to overcome thrombocytopenia associated with triple drug therapy (Peg IFN+Ribavirin+Telaprevir)

\section{Case}

A 47-year-old woman had been followed in our clinic due to $\mathrm{HCV}(+)$ cirrhosis for 6 years. She was given PEG-IFN+ribavirin treatment for 48 weeks 6 years ago. HCV RNA at the end of treatment was (-) but she relapsed soon after and SVR was not achieved. HCV genotype was genotype $1 \mathrm{~b}$. She was not given standard dual therapy regimen for the second time due to poor response rates in cirrhotic patients with relapse. After the approval of protease inhibitor-containing triple therapy regimens for the treatment of genotype 1 patients in our country, retreatment with PEG-IFN+ribavirin+telaprevir was planned. Pretreatment laboratory investigations were consistent with Child class A cirrhosis (Child Pugh score: 5, MELD score: 10) with AST: 61u/L, ALT: $104 \mathrm{u} / \mathrm{L}$, ALP: $122 \mathrm{u} / \mathrm{L}, \mathrm{GGT}: 107 \mathrm{U} / \mathrm{L}$, total bilirubin: $1.46 \mathrm{mg} / \mathrm{dL}$, direct bilirubin: $0.94 \mathrm{mg} / \mathrm{dL}$, total protein: $7.3 \mathrm{~g} / \mathrm{dL}$, albumin: $3.7 \mathrm{~g} / \mathrm{dL}$, and INR: 1.26. HCV RNA was 756000 copy/ $\mathrm{ml}$ and abdominal ultrasound showed the presence of cirrhosis and splenomegaly. Pretreatment hematologic parameters were as follows; Hb: $11.8 \mathrm{~g} / \mathrm{dL}$, WBC: 4600/ $\mathrm{LL}$, Platelet count: 64000/ $\mu \mathrm{L}$. Treatment was started with PEG IFN $\alpha-2 a 135 \mathrm{mcg} /$ week, ribavirin $1000 \mathrm{mg} /$ day and telaprevir $3 \times 750 \mathrm{mg} /$ day. After the institution of the treatment, platelet count gradually dropped to $42000 / \mu \mathrm{L}$ and then to $14000 / \mu \mathrm{L}$ in two weeks. PEG-IFN dose was progressively reduced up to $67.5 \mathrm{mcg} /$ week due to deepening of thrombocytopenia. It was concluded that corrective measures to overcome thrombocytopenia were essential for the patient to continue the treatment. PSE was preferred due to the risks of surgery and general anesthesia in cirrhotic patients. PSE was successfully performed by the interventional radiology clinic at our hospital under fluoroscopic guidance as shown in Figure 1 (preembolization) and Figure 2 (postembolization). After embolization, platelet count increased to $45000 / \mu \mathrm{L}$ in 1 week and PEG-IFN dose was increased back to $135 \mathrm{mcg} /$ week and the patient was closely followed up in terms of thrombocytopenia. HCV RNA was found to be negative after 4 weeks of treatment. Triple treatment with PEG-IFN+ribavirin+telaprevir was continued for 12 weeks without any major problems. Twelvety week

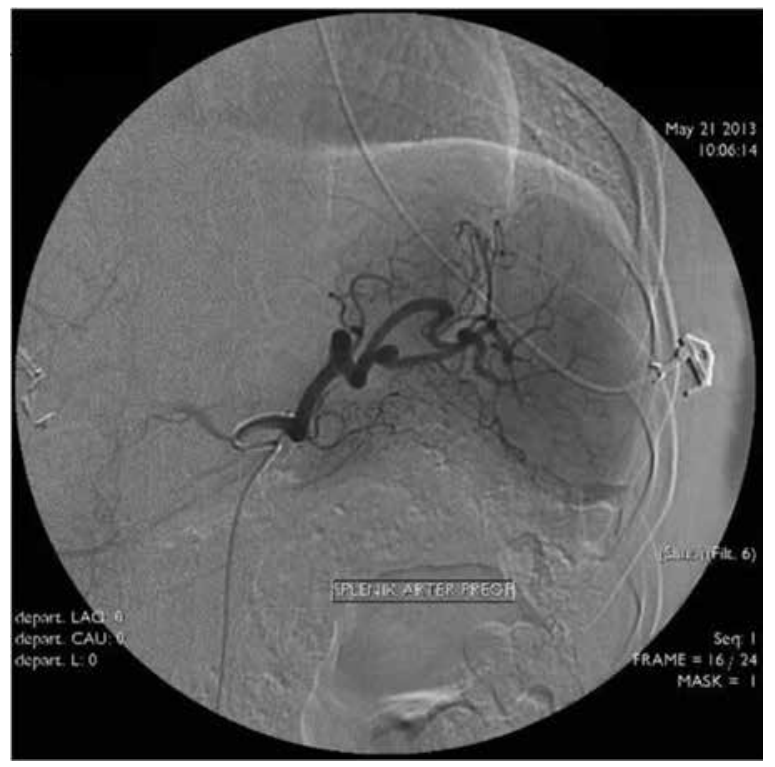

Figure 1. Splenic angiography, before the embolization

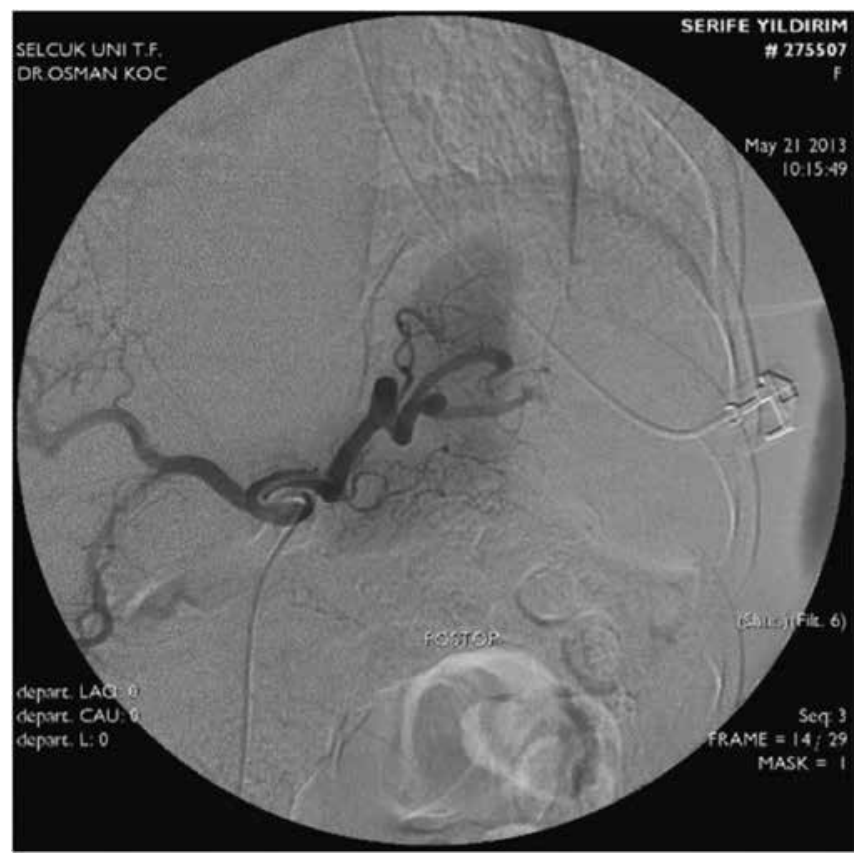

Figure 2. Splenic angiography, after the embolization 
HCV RNA was still negative, telaprevir was stopped and PEG-IFN+ribavirine was continued for 36 more weeks. She successfully completed a 48-week treatment course. Laboratory values at the end of the treatment were as follows; AST: $27 \mathrm{u} / \mathrm{L}$, ALT: $43 \mathrm{u} / \mathrm{L}, \mathrm{ALP}: 122 \mathrm{u} / \mathrm{L}, \mathrm{GGT}: 71 \mathrm{U} / \mathrm{L}$, total bilirubin: $1.05 \mathrm{mg} /$ $\mathrm{dL}$, direct bilirubin: $0.46 \mathrm{mg} / \mathrm{dL}$, total protein: $6.9 \mathrm{~g} / \mathrm{dL}$, albumin: $3.7 \mathrm{~g} / \mathrm{dL}$. Both end-treatment and $12^{\text {th }}$ week post-treatment $\mathrm{HCV}$ RNA were negative with presumed SVR.

\section{Discussion}

Despite the development of all oral drugs, IFN-containing treatment regimens are still widely used in various regions of the world for the treatment of HCV due to various reasons. One main reason is the high treatment costs of all oral drugs. On the other hand, treatment of $\mathrm{HCV}(+)$ cirrhotic patients with IFN-containing regimens is usually challenging for a variety of reasons. First of all, IFN is contraindicated in patients with decompansated cirrhosis. IFN treatment may also lead to decompansation in patients with compensated disease. Secondly, IFN treatment is frequently associated with cytopenic side effects such as thrombocytopenia and leucopenia and, cirrhotic patients usually already have thrombocytopenia mainly due to hypersplenism (7). Preexisting thrombocytopenia in these patients frequently limits the use of IFN in optimal doses throughout the treatment frequently leading to IFN dose reductions and sometimes even discontinuation of the treatment. Maan et al. (8) reported that with IFN+ribavirin therapy, IFN dose reduction rate for $\mathrm{HCV}(+)$ patients with moderate and severe preexisting thrombocytopenia was $16 \%$ and $\% 30$, respectively (8). In the same study, discontinuation of the treatment was reported in $3 \%$ of patients with moderate and $\% 16$ of patients with severe pretreatment thrombocytopenia. Another point is that, use of IFN in suboptimal doses may also decrease overall SVR rates in these patients. Thus, dealing with thrombocytopenia is important when treating $\mathrm{HCV}(+)$ cirrhotic patients with IFN-containing regimens.

Triple treatment schemes (IFN+ribavirin+protease inhibitor) are shown to be superior in terms of SVR rates to conventional IFN+ribavirin therapy for genotype 1b patients. However, triple therapy regimens are also associated with more side effects. Thrombocytopenia is one of the major concerns.

Therapeutic options to deal with thrombocytopenia in cirrhotic patients include eltrombopeg, splenectomy and PSE. Eltrombopeg is an orally active thrombopoietin-receptor agonist used for the treatment of thrombocytopenia in $\mathrm{HCV}(+)$ cirrhotic patients (9). Splenectomy is another option to treat thrombocytopenia in cirrhotic patients. Ji et al. (10) have reported that in $13 \mathrm{HCV} \mathrm{(+)} \mathrm{patients} \mathrm{with} \mathrm{decompensated}$ cirrhosis, who underwent splenectomy prior to the institution of IFN+ribavirin treatment, all patients showed improvement of thrombocytopenia and completed 48 weeks of antiviral therapy. But surgery and general anesthesia are associated with increased risk of morbidity and mortality in cirrhotic patients (11). On the other hand, PSE is an effective and minimally invasive and safe therapeutic option to treat thrombocytopenia in cirrhotic patients $(12,13)$. In a study conducted by Kondo et al. (14), it was shown that triple therapy with PEG-
IFN+ribavirin+telaprevir was well tolerated in $\mathrm{HCV}(+)$ cirrhotic patients in whom PSE was performed prior to the institution of the therapy. PSE in long term can theoretically increase the risk of infections particularly with encapsulated bacteria (15). Therefore, pneumococcal, meningococcal and haemophilus influenza type B vaccinations should be planned prior to PSE. Deterioration of liver functions and portal vein thrombosis due to decreased portal blood flow and increased platelet count are also rare complications associated with PSE.

Our patient was a HCV (+) genotype 1 b cirrhotic patient with a prior history of relapse after treatment with PEG-IFN+ribavirin. Due to poor response rates of PEG-IFN+ribavirin retreatment in patients with cirrhosis and unfavorable genotype (genotype 1b), she was not preferred to be treated with the same regimen for the second time. After the approval of protease inhibitors in genotype $1 \mathrm{~b}$ patients in our country, she was treated with telaprevir-containing triple therapy. Deepening of the preexisting thrombocytopenia complicated the treatment, but treating thrombocytopenia with PSE made it possible for the patient to successfully complete 48 weeks of therapy without any major problems.

\section{Conclusion}

In countries where the new all oral regimens are not available, IFN-containing combination therapies are still the only options for the treatment of $\mathrm{HCV}$ and protease inhibitorcontaining triple therapies are preferred for genotype 1 patients. Thrombocytopenia is a frequent complication of cirrhosis and PSE may be an effective minimally invasive option in $\mathrm{HCV}(+)$ cirrhotic patients to whom PEG-IFN based triple treatment regimens are given.

\section{Authorship Contributions}

Ethics Committee Approval: The study were approved by the Necmettin Erbakan University of Local Ethics Committee, Informed Consent: Consent form was filled out by all participants, Concept: Mehmet Asil, Murat Bıyı, Ali Demir, Design: Mehmet Asil Murat Bıyık, Ramazan Uçar, Hüseyin Ataseven, Data Collection or Processing: Sami Çifçi, Serhat Sayın, Ramazan Uçar, Orhan Özbek, Hüseyin Ataseven, Hakkı Polat, Analysis or Interpretation: Mehmet Asil, Murat Bıyık, Sami Çifçi, Serhat Sayın, Ramazan Uçar, Orhan Özbek, Huseyin Ataseven, Hakkı Polat, Ali Demir, Literature Search: Mehmet Asil, Sami Çifçi, Serhat Sayın, Ramazan Uçar, Orhan Özbek, Hüseyin Ataseven, Writing: Mehmet Asil, Murat Bıyık, Sami Çifçi, Ramazan Uçar, Peer-review: External and Internal peer-reviewed, Conflict of Interest: No conflict of interest was declared by the authors, Financial Disclosure: The authors declared that this study has received no financial support.

\section{References}

1. Leone N, Rizzetto M. Natural history of hepatitis C virus infection: from chronic hepatitis to cirrhosis, to hepatocellular carcinoma. Minerva Gastroenterol Dietol. 2005;51(1):31-46.

2. Fried $M W$, Shiffman $M L$, Reddy $K R$, Smith $C$, Marinos $G$, Gonçales FL Jr, Haussinger D, Diago M, Carosi G, Dhumeaux D, Craxi A, Lin A, Hoffman J, Yu J. Peginterferon alfa-2a plus ribavirin for chronic hepatitis $\mathrm{C}$ virus infection. $\mathrm{N}$ Engl $\mathrm{J}$ Med. 2002;347(13):975-982. 
3. Andreone $\mathrm{P}$, Colombo MG, Enejosa JV, Koksal I, Ferenci $P$, Maieron A, Müllhaupt B, Horsmans $Y$, Weiland $O$, Reesink HW, Rodrigues L Jr, Hu YB, Podsadecki T, Bernstein B. ABT450, ritonavir, ombitasvir, and dasabuvir achieves 97\% and $100 \%$ sustained virologic response with or without ribavirin in treatment-experienced patients with HCV genotype $1 \mathrm{~b}$ infection. Gastroenterology. 2014;147(2):359-365.e1.

4. Afdhal N, Zeuzem S, Kwo P, Chojkier M, Gitlin N, Puoti M, Romero-Gomez M, Zarski JP, Agarwal K, Buggisch P, Foster GR, Bräu N, Buti M, Jacobson IM, Subramanian GM, Ding $X$, Mo H, Yang JC, Pang PS, Symonds WT, McHutchison JG, Muir AJ, Mangia A, Marcellin P: ION-1 Investigators. Ledipasvir and sofosbuvir for untreated HCV genotype 1 infection. N Engl J Med. 2014;370(20):1889-1898.

5. Poordad F, McCone J Jr, Bacon BR, Bruno S, Manns MP, Sulkowski MS, Jacobson IM, Reddy KR, Goodman ZD, Boparai N, DiNubile MJ, Sniukiene V, Brass CA, Albrecht JK, Bronowicki JP; SPRINT-2 Investigators. Boceprevir for untreated chronic HCV genotype 1 infection. N Engl J Med. 2011;364(13):1195-1206.

6. McHutchison JG, Everson GT, Gordon SC, Jacobson IM, Sulkowski M, Kauffman R, McNair L, Alam J, Muir AJ: PROVE1 Study Team. Telaprevir with peginterferon and ribavirin for chronic HCV genotype 1 infection. N Engl J Med. 2009;360(18):1827-1838

7. Giannini EG. Review article: thrombocytopenia in chronic liver disease and pharmacologic treatment options. Aliment Pharmacol Ther. 2006;23(8):1055-1065.

8. Maan R, van der Meer AJ, Hansen BE, Feld JJ, Wedemeyer $H$, Dufour JF, Zangneh HF, Lammert F, Manns MP, Zeuzem S, Janssen HL, de Knegt RJ, Veldt BJ. Effect of thrombocytopenia on treatment tolerability and outcome in patients with chronic HCV infection and advanced hepatic fibrosis. J Hepatol. 2014;61(3):482-491
9. McHutchison JG, Dusheiko G, Shiffman ML, Rodriguez-Torres M, Sigal S, Bourliere M, Berg T, Gordon SC, Campbell FM, Theodore D, Blackman N, Jenkins J, Afdhal NH; TPL102357 Study Group. Eltrombopag for thrombocytopenia in patients with cirrhosis associated with hepatitis C. N Engl J Med. 2007;357(22):2227-2236.

10. Ji F, Zhang S, Huang N, Deng H, Li Z. Splenectomy prior to antiviral therapy in patients with hepatitis $C$ virus related decompensated cirrhosis. Braz J Infect Dis. 2013;17(5):601-605.

11. Ziser A, Plevak DJ, Wiesner RH, Rakela J, Offord KP, Brown $\mathrm{DL}$. Morbidity and mortality in cirrhotic patients undergoing anesthesia and surgery. Anesthesiology. 1999;90(1):42-53.

12. Takahara $M$, Miyake $Y$, Miyatake $H$, Imagawa $A$, Nakatsu $M$, Ando M, Hirohata M, Yamamoto K. Partial splenic embolization facilitates the adherence to peginterferon in chronic hepatitis $\mathrm{C}$ with thrombocytopenia. Intern Med. 2011;50(22):2731-2736.

13. Tahara H, Takagi H, Sato K, Shimada Y, Tojima H, Hirokawa T, Ohyama T, Horiuchi K, Naganuma A, Arai H, Kakizaki S, Mori M. A retrospective cohort study of partial splenic embolization for antiviral therapy in chronic hepatitis $\mathrm{C}$ with thrombocytopenia. J Gastroenterol. 2011;46(8):1010-1019.

14. Kondo C, Atsukawa M, Tsubota A, Shimada N, Abe $H$, Itokawa N, Nakagawa A, Fukuda T, Matsushita $Y$, Nakatsuka K, Kawamoto C, Iwakiri K, Aizawa Y, Sakamoto C. Safety and efficacy of partial splenic embolization in telaprevir-based triple therapy for chronic hepatitis C. Intern Med. 2015;54(2):119-126.

15. Gaba RC, Katz JR, Parvinian A, Reich S, Omene BO, Yap FY, Owens CA, Knuttinen MG, Bui JT. Splenic artery embolization: a single center experience on the safety, efŞcacy, and clinical outcomes. Diagn Interv Radiol. 2013;19(1):49-55. 